Mediterranean Journal of Humanities mjh.akdeniz.edu.tr V/1, 2015, 281-291

\title{
'Bildung' from Pages to Screen: The Artist Figures in James Joyce's A Portrait of the Artist as a Young Man and in Alan Parker's The Wall
}

\author{
Sayfalardan Ekrana: James Joyce'nin 'Bir Sanatçının Genç Adam Olarak \\ Portresi’ Romanında ve Alan Parker'in The Wall Filmindeki Sanatçı Figürleri
}

\section{Orkun KOCABIYIK*}

\begin{abstract}
Mikhail Bakhtin's assertion of the term Bildungsroman signifies "the image of man in the process of becoming" (Bakhtin 1986, 19). In general terms, the Bildungsroman is a novel of "building" or growth and development. In his well-known novel "A Portrait of the Artist as A Young Man", Joyce portrays the growth of the novel's protagonist Stephen Dedalus that leads him to become an artist. Likewise, Pink as the protagonist in the famous movie and album "The Wall", reflects the same development as Stephen Dedalus, but ends with the destruction of the artist himself both physically and psychologically. For example, the director Alan Parker focuses entirely on the character's devastating side, whereas James Joyce only deals with his flawed aspects, and ends his novel with the constructive feature of mental and physical separation from Irish society. Taking the definition of Bildung as the theoretical background, the heroes of both works of art will be compared and contrasted in terms of their "Bildung" process. With this, it will also be illustrated how literature and media address the process of "Bildung" in terms of their own style of narration.
\end{abstract}

Keywords: Bildungsroman, James Joyce, Pink Floyd, Hero, The Figure of the Artist

Öz: Mikhail Bakhtin'e göre Bildungsroman “olgunlaşma sürecindeki insan imgesini” (Bakhtin 1986, 19) temsil etmektedir. Genel anlamda Bildungsroman bir karakterin olgunlaşma ve büyüme sürecini ana motif olarak alan roman türüdür. En bilinen romanlarından biri olan "Bir Sanatçının Genç Adam Olarak Portresi”nde James Joyce, romanın ana karakteri olan Stephen Dedalus'un sanatçı olma yolundaki olgunlaşma ve büyüme hikâyesini aktarmaktadır. Aynı şekilde, yönetmen Alan Parker'in 1982 yapımı “The Wall” filmindeki ana karakter Pink de, Stephen türünden bir büyüme sürecindedir. Fakat Pink'in içinde bulunduğu bu süreç Stephen'ınkinden farklı olarak sanatçının yok olması yolunda bir süreçtir. Örneğin Parker ana karakteri olan Pink'in tahripkâr tarafını ön plana çıkarırken, Joyce ise Stephen'ın sadece zararlı yönlerini ortaya koymakla yetinir ve bu yönünü, romanın ilerleyen kısımlarında onun, toplum içinde bir sanatçı olması yolunda bir araç olacaktır. Bu çalışmada "Bildungsroman" terimi kuramsal arka planda ele alınarak, bahsi geçen sanat eserlerindeki "kahramanları" olgunlaşma ve birer sanatçı olarak büyüme süreçleri karşılaştırılacaktır. Bu anlamda iki farklı sanat türünün kendine özgü anlatım yöntemleriyle kahramanın büyüme ve olgunlaşma (Bildung) sürecini ne biçimnde ortaya koyduğu gösterilecektir.

Anahtar sözcükler: Bildungsroman, James Joyce, Pink Floyd, Kahraman, Sanatçı Figürü

\footnotetext{
* Yrd. Doç. Dr., Muğla Sıtkı Koçman Üniversitesi, Edebiyat Fakültesi, Batı Dilleri ve Edebiyatı Bölümü, Muğla. orkunkocabiyik@mu.edu.tr
} 
"The term Bildungsroman was introduced to the critical vocabulary by the German philosopher and sociologist Wilhelm Dilthey (1833-1941)" (Boes 2006, 231). But his academic writings "were not translated into English until the 1950s but the word itself made its way across the Channel as part of the lexical infusion that arose from Edwardian interests in the writings of German thinkers such as Sigmund Freud, Max Weber, and Georg Simmel" (Boes 2006, 231). Apart from the basic definition in "Encyclopaedia Britannica," Susanne Howe's "Wilhelm Meister and His English Kinsmen", has been considered as the first academic work on the subject, which was published in 1930. For the last several decades, however, "the primary reference to the British novel of the formation has been Jerome Hamilton Buckley's 'Season of Youth: The Bildungsroman from Dickens to Golding'” (Boes 2006, 232) was published in 1974 and gives a broad definition of term Bildungsroman. According to Buckley, a Bildungsroman portrays some fundamental characteristics, among which he includes the following: "childhood, the conflict of generations, provinciality, the larger society, self-education, alienation, ordeal by love, the search for a vocation and a working philosophy" (Buckley 1974, 18).

Another prominent scholarly contribution to the subject appeared in the 1980s, ten years after Buckley's work. Mikhail Bakhtin's “The Bildungsroman and Its Significance in the History of Realism" had been written forty years before Buckley's work but the manuscript tumbled into obscurity together with its author [Bakhtin] (Boes 2006, 236) and the English speaking world could not read his works until two American scholars Michael Holquist and Caryl Emerson translated the Russian published text and edited it for Anglo-American audiences in 1986 (Bakhtin, as a literary critic, generally associated with the school of Russian Formalism. Because of his controversial opinions, he was arrested in 1929 and exiled to Kazakhstan, where he had to live there until 1936. The large part of his works were composed during this exile period. As Roza Lambrechts also states that, “during Soviet reign Bakhtin's theories did not reach a wide audience. It was not until the 1980s that his theories became popular in the West and gained critical acclaim ever since” Lambrechts 2008, 2). Michael Holquist, in the preface to Bakhtin's Dialogic Imagination submits a short story that gives detailed insight into Bakhtin's character: "In 1936 [Bakhtin] ... finished work on a major book devoted to the eighteenth-century novel. This manuscript was accepted by the Sovetskij Pisatel Publishing House, but the only copy of it disappeared during the confusion of the German invasion [...] The only other copy of this manuscript Bakhtin - an inveterate smoker - used as paper to roll his own cigarettes during the dark days of the German invasion" (Holquist 1981, xv-xxxiii). Another prominent American author, Paul Auster points out the smoking habits of Bakhtin as follows: "There is also M.M. Bakhtin, the Russian critic and literary philosopher. During the German invasion of Russia in World War II, he smoked the only copy of one of his manuscripts, a book-length study of German fiction that had taken him years to write" (Auster 1987, 255). Unfortunately, the original book-length manuscript had only survived in fragments; "Bakhtin, $a$ heavy smoker, literally consumed the pages of his work when he used them as rolling papers during the German invasion of the Soviet Union” (Boes 2006, 232). Luckily, the surviving remains are sections from the introductory parts of his book. From these sections, at least one can easily comprehend Bakhtin's main intention concerning this subject. Through this one understands that Bakhtin argued that the Bildungsroman offers "the image of man in the process of becoming" (Bakhtin 1986, 19), and puts its protagonist at the edge between different historical periods:

"[The Hero] emerges along with the world and he reflects the historical emergence of the world itself. He is no longer within an epoch, but on 
the border between two epochs, at the transition point from one to other. This transition is accomplished in him and through him... It is as though the very foundations of the world are changing, and man must change along with them" (Bakhtin 1986, 23-4).

In more general terms, the Bildungsroman is a novel of "building" or growth and development. In his well-known novel "A Portrait of the Artist as A Young Man", James Joyce portrays the specific process of the novel's protagonist Stephen Dedalus that leads to his becoming (in Bakhtinian terms) a writer/artist. Likewise, Pink as the protagonist in the movie/documentary "The Wall" reflects the same development as that of Stephen Dedalus, however, it ends with the vanishing of the artist both physically and psychologically. For example, the director Alan Parker focuses entirely on his hero's destructive side, while James Joyce highlights his character's constructive side in the separation from society. Through this primary difference, this study aims to compare and contrast Stephen and Pink as "developing" characters and with this, the attempt is also made to illustrated how the literate and the media show the process of 'bildung' in terms of their own narrative techniques.

People living in hoarder and hunter-gatherer societies had no artists within the terms of the contemporary understanding of the definition of the word 'artist'. When society became complex enough to sustain the division of the 'workforce', artists emerged first as shamans in history, afterwards as painters, sculptors, singers, and writers, then one can think within the contemporary definition of the term "artist". Thus, while society builds, generates or produces the 'artist', the same society can also destroy him/her.

James Joyce published his novel in 1916, as a revised version of an earlier unpublished work entitled "Stephen Hero". Joyce had nearly destroyed the manuscript of "Stephen Hero" after a harsh quarrel with his wife Nora. Joyce would later reuse many ideas from "Stephen Hero" in his famous novel "A Portrait of the Artist As a Young Man". The novel is partially autobiographical, and a novel of education "through self-cultivation" (Even the dictionary meaning of this term has been defined as the process of educating yourself; a North American theologian Kwok Pui-lan elaborates the term self-cultivation in more broder sense: "Learning is not as grasping intellectually a body of metaphysical or abstract eternal truth. In the Confucian tradition, learning is for the cultivation of the individual person and the ordering of human society... Self-cultivation, in the Confucian sense, is the process of the broadening of the self to embody an ever expanding circle of human relatedness" (Kwok 1995, 36), (Bildung) which narrates the experiences of a young Irishman Stephen Dedalus from his early childhood to his youth. The protagonist Stephen Dedalus is an intelligent child with limitless curiosity. Joyce gives the reader this feeling in the form of a foreshadowing before the novel begins. The book begins with an epigraph from Ovid's Metamorphoses: "Et ignotas animum dimittit in artes" which is translated as: "and he sent forth his spirit among the unknown arts". The quote foreshadows some aspects of the inner life of Stephen, who is obsessed with a persistent pursuit of truth, beauty and knowledge. The novel reflects the young Stephen's inner thoughts and feelings during his early childhood, and follows the transition from childhood and youthful innocence to maturity. Joyce's novel has been considered as a coming of age tale of young Stephen Dedalus who desires to be an artist. However, he is haunted by several doubts about his destiny and the novel continues with his numerous epiphanies. The novel shows the reader the life of Stephen from his early days to a Catholic school, where he is taught Christian theology.

The director of "The Wall”, Alan Parker grew up a "working class boy in London, and gained fame in the second half of 1970s after a fruitful career of writing and directing TV 
commercials" (www.alanparker.com). Among his famous projects, "The Wall" (1982) has a prominent place. Irish singer Bob Geldof acted as Pink in the movie, who is a mentally collapsed artist, who has shifted from an optimistic child artist to a perished rock idol venturing away from 'real' life. The protagonist of the movie, Pink, is loosely based upon the rock band Pink Floyd's founder 'wild' Syd Barrett, who was cast out from Pink Floyd for his erratic and disturbed behaviour, to briefly undergo psychiatric care, before releasing two solo albums. Roger Waters, the bass player of Pink Floyd and the film's script writer, "knew exactly how the audience would react toward the film even as he designed the poster for it, which offers vivid snatches of several scenes scattered around the main character Pink" (Lawrence 1997). As a narration of story, "The Wall" differs from any conventional form of narration and story telling. The audience try to determine what is going on in the theme through watching the flow of images on the screen together with Pink Floyd's ballads. This biographic film relates the story of Pink (Bob Geldof), a rock idol who has to confine himself to a hotel room while thinking back on his childhood. Subsequently, the film makes clear that Pink grew up fatherless (killed in World War Two when Pink was a small child) with a dominant and anxious widow mother. Moreover, when Pink was young, the school system did not appreciate his creative talent in the classroom. Later, he marries a woman with whom he was unable to connect, and consequently she finds her solution through betraying him. All these elements: his father, his relationship with his mother, his education, and his wife, are factors that edge Pink to choose to sit isolated on his own in a hotel room, which might be considered one of the climaxes of the movie: all of the above factors are metaphors of the bricks in the psychological wall that Pink constructs in, and outside himself. Figuratively "the wall represents the barrier Pink has surrounded himself with so that he does not have to deal with the realities of the outside world" (Mason 2005, 21). So he sits behind his wall, drinking, taking drugs, and goes through several phases of psychological breakdown until he becomes insane.

One of the fundamentally important similarities between both characters is their separation from their social environment. Joyce believes that "the separation from society is important for an artist in order to see the society clearly" (Castle 2003, 667). The first chapter of the novel portrays Stephen as an individual isolated from his circle, and undergoing many encounters with authorities, which reappears in different forms throughout the narration. According to Castle, "ordinary or common people are easily influenced by authority figures, as Dante and other Irish Catholics are against Parnell by the church's condemnation, or by other trendy movements such as the peace testimonial, all of which are rejected by Stephen in the end" (Castle 2003, 669). While Stephen is describing the beauty of the basket, his discourse is quite philosophical: "your mind first of all separates the basket from the rest of the visible universe which is not the basket. The first phase of apprehension is a bounding line drawn about the object to be apprehended" (Joyce 1976, 212). Thus, in addition, if an artist is the one who perceives society clearly, a border should be drawn around the society separating the artist from it in order for him to observe it; it is difficult to comprehend the pattern of the society from inside its complexities and structure. But when it is observed from the above or outside, the paths in and out might become more visible for the artist. The artist should be the one who stands outside the society "changeable way of thinking of the average human being in order to discover the universal that keeps people still reading Greek myths or Shakespeare after centuries” (Silva 2013, 5-6). Pink Floyd relates this separation from the society, with the metaphor of the wall of bricks, which has a crucial role throughout this musical movie.

The separation from the society and the social environment for both Pink and Stephen as artists begins in their early childhood, and this becomes obvious in their interactions with their 
peers and females. A supporting aspect to their increasing act of their separation from society is the way in which they are educated. The School as an institution that is supposed to develop the minds of children has harmful effects upon both young artists. The teachers, who are supposed to be the ideal guides for their pupils in enabling them to realise their potential, are portrayed as severe and authoritarian in Alan Parker's movie. In similar ways, Stephen is punished in an unfair manner for having broken his eyeglasses, while the other pupils in the class mock Pink's poetry. The teacher discovers Pink's poems and punishes him by reading his poem loudly in the classroom. At the same time, he has also mocked by Pink's peers in the class, before the scene depicting a smack on his hand with a wooden stick wielded by the severe teacher. In the next snapshot, the teacher as usual continues the maths lesson, nailing the definitions into the heads of the pupils through perpetual repetition. This method of "learning" resembles Aldous Huxley's definition of "hypnopedia" (the dictionary definition of this term is "sleep-learning") described in his famous volume, "A Brave New World", during the course of which, it is related definitions are "repeated to sleeping infants by a machine so that, after hearing the lesson countless times in their sleep, the young children will accept the formulas as fact. Such subtle brainwashing in Huxley's novel, much like the techniques used by Pink's teacher to mould the children into 'proper members of society' results in a strictly enforced caste system and shapes the bio-engineered children into the 'model' citizens" (Blake 2012, 6). Pink expresses his opinion of the education system through the band's most iconic words:

\section{"We don't need no education \\ We don't need no thought control \\ No dark sarcasm in the classroom \\ Teachers leave the kids alone... \\ All in all you're just another brick in the wall".}

The above lyrics, written and composed by Roger Waters, seem to be the expressions of a truly tortured soul, in terms of both Pink and also Roger Waters himself. This also indicates that "The Wall" is based upon his own experiences as a famous rock idol. It is no coincidence that like Pink, Roger Waters also had a father who died during the war and also had an unsuccessful marriage. For a specific example of self-referentiality in the film's script, Waters' 1979 interview with Tommy Vance can be cited. Waters describes the bricks of the wall as Pink "convincing himself really that his isolation is a desirable thing" (Vance 1979). The other self-reference in the movie can be observed in the poem that is written by Pink himself in the class. The poem that was written by Pink in the class is in essence, the lyrics of the famous Pink Floyd song "Money," possibly employed by Waters to mingle the edges of fact and fiction, suggesting Pink's past desire to be wealthy and famous, along with foreshadowing his upcoming success as a famous rock star.

Also for both of these characters, Pink and Stephen, in their "family life, neither receives the affection or sympathy they need in order to learn to identify with or to interact meaningfully with the people in their lives. Stephen's mother is a 'nice mother'" (Joyce 1976, 9) but she has significantly little personal traits. Stephen's mother has been portrayed as an illiterate who does not manage to hold any opinion concerning any subject. For example, during one of the Christmas dinners, the alert reader can easily note that her only role is of trying to prevent an imminent argument. Her point of view is generally shallow and she can only recognise the outward appearance of things or ideas. At the dinner table she declares: "Well, it is perfectly dreadful to say that not even for one day in the year..., can we be free from these dreadful disputes!" (Joyce 1976, 34). She is not nearly as concerned about the authenticity of the 
arguments; it is the "saying" of these arguments that is dreadful. She is concerned and worries about Stephen, and gives him a motherly caution by mentioning, "not to speak with the rough boys in college" (Joyce 1976, 9) and this shows mainly her weak side as a mother. Moreover, Stephen rudely gives her an order to: "fill out the place... to wash" (Joyce 1976, 175), and then she transmits this order to her daughter Katey, who in turn, passes the order onto a younger sibling, which shows how much respect her children give her. On the other hand, Mr. Dedalus is not also acting as a householder. In one of the scenes, in a humiliating manner he whistles, calling or ordering the females in his family. Through this idea, as a father figure he advises Stephen before he begins going to school to: "never to peach on a fellow" (Joyce 1976, 9). Mr. Dedalus seems to be, not much of suitable role model but rather, behaving himself as another adolescent. Another time, he mocks a hotelkeeper during the Christmas party, behaves without sympathy or kindness to Dante, and afterwards, brags about himself that he could defeat his son in competitions. He states once in a pub that "I'm a better man than he is any day of the week" (Joyce 1976, 95), and later calls Stephen a "lazy bitch" (Joyce 1976, 175) exposing his own variant of fatherly devotion that Stephen had anticipated earlier. Stephen's relatives are merely labels on the page, one cannot find any intimate connection described between him and them.

Pink, on the other hand, is the only child and his father died in the war. Therefore his relation with his family is generally centred upon a domineering mother figure. In a 1979 conversation with Tommy Vance, Waters states, "if you can level one accusation at mothers it is that they tend to protect their children too much. Too much and for too long. That's all. Having lost her husband, one can easily imagine through Pink's lyrics a mother who is trying her absolute best to keep her only son 'under her wing,' away from harm and the fate that took her husband" (Vance 1979). Sadly, for Pink, such an exaggerated overprotection ends up with the mental projection of his mother's concerns and anxieties on to him. She probably blames herself that she couldn't save her husband from an unfortunate death, but she will do her utmost to preserve the only remaining piece of him that is left to her in the form of Pink, who also undergoes a similar destiny. Nonetheless, Roger Waters clearly suggests, "such motherly protection can turn stifling for a person searching for autonomy. Instead of inspiring him to greatness, Pink's mother tries to keep him 'cozy and warm'” (quoted in Vance 1979). Through this, in terms of the preservation of his mother, Pink believes that, the more she directs him to keep him safe in an excessive manner, the more she pushes him into being isolated from the rest of the world. While she is trying to get rid of the harm, she harms his son in his innermost centre. One might see this process related in the following lyrics from the movie:

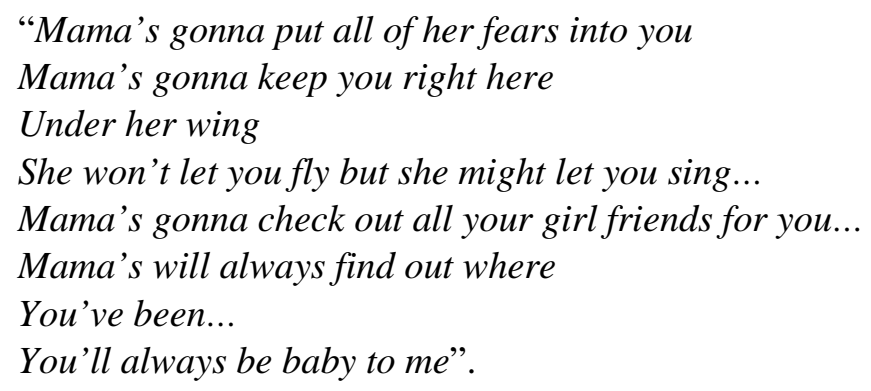

Through Alan Parker's snapshots, the mother is depicted as insensitive overprotective character far from affectionate. There is only one scene in which one might even see Pink physically able to approach his mother, and that is while she is sleeping in serenity. As a typical portrayal of a depressive character, she never attempts to smile or reach out to her son. One example of this can be seen when Pink was a baby. In the beginning of the movie, she does not hold him at the 
park but sits separately from her son while he (Pink) cries in a baby carriage. A critical reading of this mother-son relationship might be seen in Freudian sense in terms of Pink and Stephen:

"Freud might agree that given the relationship the two artists have with their mothers, naturally they would have problems with their sexuality, which contributes to their isolation. For Stephen, a woman is either the Virgin Mary or the whore of Babylon. When he was young, he only identifies the Virgin Mary aspect of the female, explaining the Tower of Ivory of the litany of the Blessed Virgin through Eileen's long white hands. When his hormones become a more driving factor in his life, he experiences the other kind of a woman as he frequents the beds of prostitutes" (www.drop-of-ink.com).

As Stephen is not capable of interacting with the opposite sex in any other way, his connection with women are merely material, as his interaction with males are completely intellectual. As a result of this, he begins to hesitate between these aforementioned two types of women: he accuses Eileen "of flirting with a priest" (Joyce 1976, 216). He thinks about Eileen that she might have been innocent in the past, but in fact, that was when "the strange humiliation of her nature had first come upon her" (Joyce 1976, 222). Despite of, or because of his denial of the Catholic Church, his strong belief as to 'original sin' surrounds his conception of the opposite sex. He mentions that "Pascal . . . would not suffer his mother to kiss him as he feared the contact of her sex... the church calls him a Saint" (Joyce 1976, 242). All in all, Stephen's eventual thoughts in respect to Eileen are, "O, give it up, old chap! Sleep it off!” (242).

Similarly, apart from Pink's mother, the maternal characters in "The Wall," are his partner/ wife and the "dirty woman", we do not hear her actual name. For his partner, Pink is unapproachable and in one of the scenes, we notice that he constantly drinks alcohol and practices at his music; and during his engagement, he does not respond either to her appearance nor to her conversa-

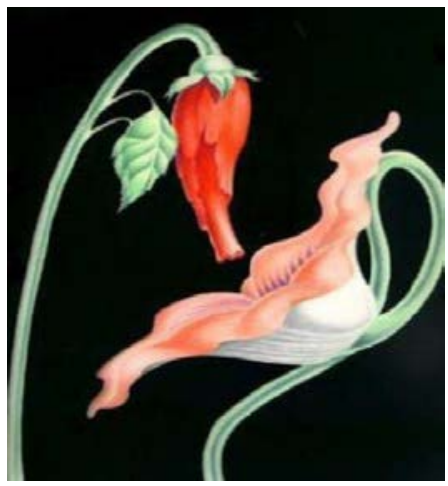

Fig. 1

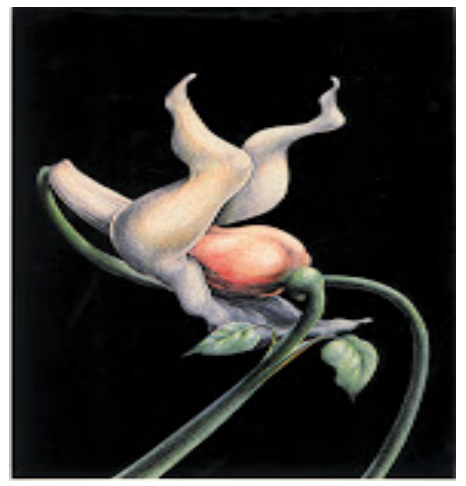

Fig. 2 tion. Contrary to Stephen, he is incapable of interacting with women, even at a bodily level. In another scene, which deals with his marriage, we notice that his kiss to the bride (his partner/wife) is senseless and mechanical. Other surprising scenes include the one in which two flowers entrap each other in the simulated scene of love; the female destroying the male after sexual intercourse (shown in Figure 1 and 2 above). "Two flowers might refer to represent the male and female genitalia. The female lovingly coaxes the male to enter, then devours him, transforming into a monstrous black thing" (Parker 2013). This echoes Stephen's opinions concerning Eileen that women who formerly were innocent become 'domineering and impure'. (Fig. 2, All the drawings belong to Gerald Scarfe for this musical movie. The above-mentioned flowers, dancing with each other before joining one another, flowers turning into a cannibalistic creature. The female savagely devours the male).

Another female figure in "The Wall" is the groupie and she intends to enter Pink's vicinity through sexuality, as she fond of his vagabond style. When Pink has fainted in front of the TV 
set, "she attempts to relieve his apparent sadness through sensuality" (Mason 2005), which ends up in his breaking up everything in the hotel room. Moreover, he is incapable of responding properly to any kind of bodily expression.

To provide an analogy, both Stephen and Pink experience a deep void in their lives and try to balance this emptiness through tangible things. Stephen goes to visit prostitutes while Pink interrogates the empty spaces:

"What shall we use to fill the empty
Spaces where we used to talk
How shall I fill the final places
How shall I complete the wall?".

In a further striking scene - when the cartoon cars and hi-fis are plugged in to the sky and where the scene flashbacks serve as bricks in the Wall - the movie takes us into a rare "condemnation of an obsessive consumer culture building walls of meaningless junk and amplifies it through a loudspeaker" (Urick 2010, 5). The shouting visage coming out of the Wall, together with the haunting flowers with their sexual connotations are only two traditional graphic images, amongst others, emerging from Gerald Scarfe's perception of the scriptwriter's (Roger Waters) text through the protagonist of the movie.

In comparison, both characters consider this life as depressive and they direct themselves to the opposite of their artistic capability and experience. Thus, Stephen turns to a religious extreme and tries to put his life to order through participating in religious doctrine and evolves into an ideal student. As Buckley also points out, with "the suggestion that he be a priest and devote himself to such a life, he realizes that it is no more fulfilling than the life based on materialism he had rejected" (Buckley 1974, 24). By the same token, Pink wipes out everything in his isolation cell of a hotel room, but he soon afterwards occupies himself classifying the blasted leftovers of his belongings into intricate symmetrical shapes (Fig.5). In addition, Pink shaves his body together with his eyebrows in an aggravating manner to cast off the animalistic nature of his corpus, and then he tries to commit suicide (Fig.3). In fact, Syd Barrett, the founder of the band Pink Floyd, essentially went insane because of his profound psychedelic drug abuse: "through late 1967 and early 1968, Barrett's behavior became increasingly erratic and unpredictable, partly as a consequence of his reported heavy use of psychedelic drugs, most prominently LSD" (Palacios 1997, 22). The scene in which Pink shaves all his bodyhair along with his eyebrows was inspired by a real event: "Barrett was so mentally ill that he was once eating dinner with a large group of people, got up, went and shaved his head and eyebrows, and then sat back down to dinner with his guests as though nothing had happened" (Urick 2010). Another similar incident took part in 1979: "by that time, the 29-year-old Barrett had become quite overweight, had shaved off all of his hair (including his eyebrows), and his ex-bandmates did not at first recognise him. Barrett's behaviour at the session was erratic; he spent part of the session brushing his teeth" (Palacios 2010, 408).

In conclusion, the Irish society in "A Portrait of the Artist as a Young Man" has here been revealed as just absurd and insensitive; while in "The Wall" society has likewise been disparaged. Apparently, the society in "The Wall" is represented through the symbolic motif of the hammer, which cracks every human being (Fig. 4). In a further sequence the mechanism of the school, having the form of a factory rather than a school, takes the students and minces them up so that they become simply standard undifferentiated minced-meat. Just as in "A Portrait of the Artist as a Young Man," one might see the "common man as contemptible and conforming to the 
whims of the society both in the screaming rabble that make up the crowd or the eerie, bulbous faces on the train" (Scarfe 2011, 32). Stephen carries out his role of an artist/writer by changing his state of mind into a "tutor-shaman" as he explains his theory about aesthetics to his friend Lynch and thus enables him to go into the world of wisdom, like some sort of travelling cleric or sage. Detached from society, he will be the one who gains the personal outlook to investigate and observe the realities of the norms and taboos of the current society.

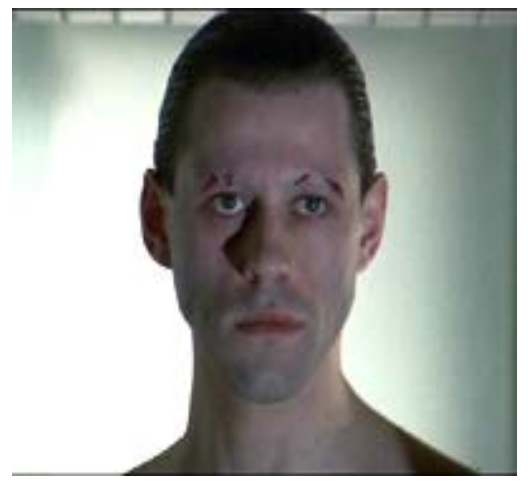

Fig. 3

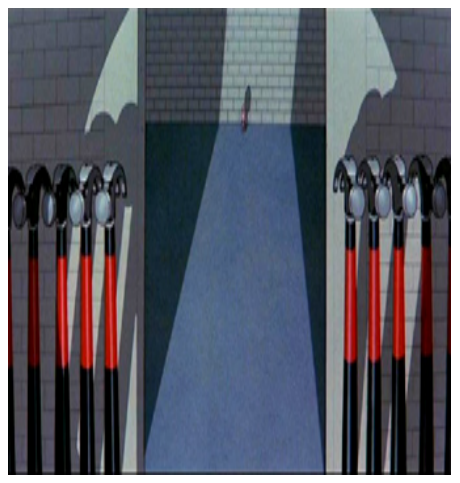

Fig. 4

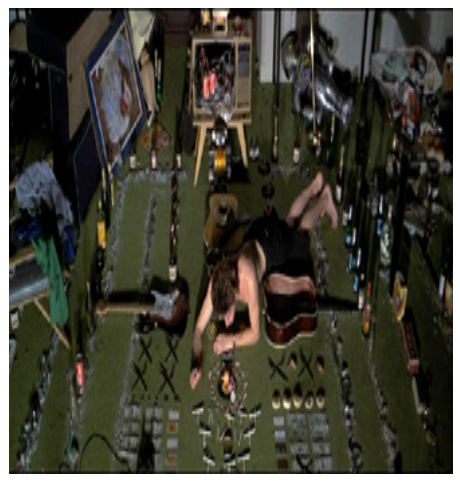

Fig. 5

Conversely, "Pink's isolation, utterly destroys him. Unable to endure his pain, the wall is torn down by the hammer of conformity and Pink becomes the very personification of repressive society. If the role of the artist is to objectively show the society the truth of itself, then Pink emerges as an artwork in himself, an accurate mirror of the forces that shaped him" (Parker 2013). Pink's self-cultivation works in a different manner from that of Stephens' selfcultivation. Undeniably, Pink transforms throughout his inner travelling, from a young spotty boy moving to his adulthood by symbolically walking through the "high on drugs" of the rock idol of his maturity. It is very obvious that Pink "has become comfortably numb" (this being a lyric in and title of a quintessential Pink Floyd song) to his psychological "pain and past so that he swims in his most painful memories with a sense of nostalgia" (Vance 1979). One might clearly see (as an audience) where Pink is heading through with the images in the movie and also look at him with pity and melancholy as a reverse-developing hero/anti-hero. In his interview with Tommy Vance, Waters draws a parallel between Pink's childhood and Syd Barrett himself stating that, "when he was a child he saw a sudden glimpse out of the corner of his eye but he turned to look at, it was gone. The child must grow and his dream is gone. Pink's wall slowly went up over the years until he is finally forced to tear it down" (Vance 1979). The "Bildung" process of both Stephen and Pink works differently: while Pink's isolation pushes him to destruction, the same isolation by means of the pressure of Irish society, leads Stephen to become an artist/writer. In two different styles: the visual and written representations of abovementioned heroes/anti-heroes have been taken as examples of the "Bildung" process, a process which in the end, pushes both characters to divergent ends. Joyce's treatment of Stephen as a developing character in terms of the process of becoming by changing his state of mind due to the effect of Irish society is promising for the reader. On the other hand, taking the "Bildung" narration as a visual story related in his movie, Alan Parker chose to be more pessimistic in drawing a close connection with Pink and Syd himself. All in all, the visual musical bildung process of Pink as a literary anti-hero becomes in the end a lonely rock artist in the presence of the audience. In turn, the turning point in Stephen's life, it leads to the life-changing decision that the hero makes, soon after, to pursue a life in writing as an artist. This decision of Stephens contrasting with Pink's renunciation of singing on the stage in Parker's movie are the basis for 
the novel's and movie's implicit associations, in terms of two different "Bildung" processes. While so-called artistic independence liberates Stephen, this same artistic freedom constrains Pink and leads him to a destructive end. Stephen may seem a hesitated young man at the beginning of this process of becoming, but later, he breaks out of his confusion to emerge as a very determined individual. By observing his own freedom through his Catholic environment, Stephen chooses to be identified as an artist. In the end, Stephen confronts us as an existential character that possesses the awareness of his own process of becoming, in other terms the "Bildung" process. He has the responsibility to carry his responsibility as an artist. Similarly, as a rock star, Pink's musical story is as universal as that of Stephen's in how both characters deal with their becoming artist/writer. His peers have attempted to manipulate Pink's life, such as his mother, teacher, and spouse, as in the same way, Stephen's life has been shaped by his parents, together with conservative society, which surrounds Stephen. Although the details of their "bildung" process are doubtless different, the underlying themes of humanity are universal, both in "The Wall" and "A Portrait of the Artist As a Young Man", themes such as the process of becoming of a hero in terms of an existential search, responsibility as an artist, and resisting the values of the society. These themes apply to our lives, quite as much as they apply to the stories of Pink and Stephen's fictional "bildung”.

\section{List of Figures}

Figure 1: http://floydlyrics.blogspot.com.tr/2010/03/what-shall-we-do-now.html [10.12.2014].

Figure 2: http://floydlyrics.blogspot.com.tr/2010/03/what-shall-we-do-now.html [10.12.2014].

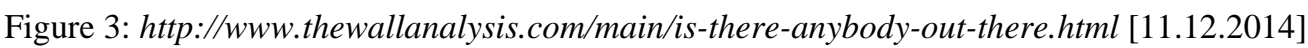

Figure 4: http://www.thewallanalysis.com/main/is-there-anybody-out-there.html [11.12.2014]

Figure 5: http://www.thewallanalysis.com/main/is-there-anybody-out-there.html [11.12.2014]

\section{REFERENCES}

Auster P. (1987). The New York Trilogy. New York 1987.

Bakhtin M. (1986). "The Bildungsroman and Its Significance in the History of Realism (Toward a Historical Typology of the Novel)”. Eds. C. Emerson and M. Holquist. Speech Genres and Other Late Essays (1986) 1-60. Trans. V. W. McGee. Austin 1986.

Bayha M. (2013). Pink Floyd “The Wall” - Eine Abrechnung Mit Der Popkultur?. Saarbrucken 2013.

Blake M. (2012). Nos Bastidores do Pink Floyd (Behind the Scenes of Pink Floyd). Trans. Alexandre Callari. Sao Paulo 2012.

Boes T. (2006). "Modernist Studies and the Bildungsroman: A Historical Survey of Critical Trends". Literature Compass 3/2 (2006) 230-243.

Buckley J. H. (1974). Season of Youth: The Bildungsroman from Dickens to Golding. Cambridge 1974.

Castle G. (Summer, 2003). “Coming of Age in the Age of Empire: Joyce's Modernist 'Bildungsroman””. James Joyce Quarterly 40/4 (2003) 665-690.

Ebert R. (2010). Pink Floyd: The Wall. 24 February. Roger Ebert.com. Available: http://www.rogerebert. com/reviews/great-movie-pink-floyd-the-wall-1982. Accessed 29 September 2014.

Holquist M. (1981). The Dialogic Imagination: Four Essays. Austin 1981.

Johnson A. (2010). Review: Pink Floyd-The Wall. 17 May. The Kuleshov effect. Available:http://www. thekuleshoveffect.com/index/2010/5/17/review-pink-floyd-the-wall-1982.html. Accessed: 28 September 2014.

Joyce J. (1976). A Portrait of the Artist as a Young Man. New York 1976.

Kwok Pui-Lan (1995). Discovering The Bible in the Non-Biblical World. Maryknoll 1995.

Lambrechts R. (2008). The Quest For Identity: Self versus Other in Paul Auster's 'The New York Trilogy'. 
Unpublished M.A. thesis. Ghent University, Belgium. via http://lib.ugent.be/fulltxt/RUG01/001/ 414/977/RUG01-001414977_2010_0001_AC.pdf Accessed: 20 April 2015.

Lawrance M. (1997). “Cinema Stardust: Pink Floyd The Wall”. Via http://www.towerofbabel. com/sections/film/cinemastardust/wall.htm [25.10.2014].

Mason N. (2005). Inside Out: A personal history of Pink Floyd. San Francisco 2005.

Palacios J. (1997). Lost in the Woods: Syd Barrett and the Pink Floyd. London 1997.

Palacios J. (2010). Syd Barrett \& Pink Floyd: Dark Globe (Rev. ed.). London 2010.

Parker A. (2013). "Pink Floyd The Wall: The making of the film, brick by brick". Via http://alanparker. com/film/pink-floyd-the-wall/making/. Accessed: 28 August /2014.

Sony Wonder Studios (Producer) \& Parker A. (Director). (1982). The Wall.[Film]. Metro-Goldenwyn Mayer.

Scarfe G. (2011). The Making of Pink Floyd The Wall. Cambridge.

Silva Otaviano da Jose (2013). "Goodbye Blue Sky: The Second World War in Pink Floyd's The Wall”. Revista Brasileira da Cancao, 3, jan-jun. www.rbec.ect.ufrn.br.

Thompson D. (2013). Roger Waters: The Man Behind the Wall. London and New York 2013.

Urick B. "Pink Floyd's The Wall: A Complete Analysis." 2010. www.thewallanalysis.com/main. [12.10.2014].

Vance T. Interview with Roger Waters, BBC 1, [30.11.1979].

www.alanparker.com/biography. [30 October 2014].

www.drop-of-ink.com/pinkfloyd [23 September 2012]. 